\title{
Treatment Options for Patients with Brain Metastatic Disease in HER2-Positive Breast Cancer
}

A 50-year-old postmenopausal female who had early breast cancer (ER-PR- and HER2+) was initially treated with surgery (pT2N1M0), followed by 6 cycles TCH (docetaxel, carboplatin, and trastuzumab) and maintenance trastuzumab for 1 year. Six months after completing trastuzumab, she presented with headache, and magnetic resonance imaging (MRI) of the brain revealed multiple bilateral brain metastases. Positron emission tomographycomputed tomography revealed no other systemic disease. After whole-brain irradiation, she was treated with ado-trastuzumab emtansine (TDM-1). After 4 cycles of the same, a repeat MRI brain showed stability of prior lesions, but a few new lesions suggestive of disease progression. There was still no evidence of any other systemic disease. She has no comorbidities, Eastern Cooperative Oncology Group performance status 1, and all blood tests were within normal limits. How should we treat her?
A. Lapatinib + capecitabine
B. Tucatinib + trastuzumab + capecitabine
C. Neratinib + capecitabine
D. Pyrotinib + capecitabine
E. Trastuzumab + capecitabine
F. Trastuzumab deruxtecan (DS-8201a)
G. Any other.

The outcome of HER2-positive advanced breast cancer $(\mathrm{ABC})$ has significantly increased with the advent of anti-HER2 therapies. The CLEOPATRA trial update showed that patients with HER2-positive ABC treated with docetaxel, trastuzumab, and pertuzumab had an 8 -year overall survival (OS) of $37 \% .^{[1]}$ Patients with hormone-positive status, metastasis limited to nodes/local site, and use of trastuzumab had shown to improve survival in HER2-positive $\mathrm{ABC} .^{[2]}$ The summary of the trials in HER2-positive ABC is shown in Table 1.

The preferred treatment option would be tucatinib + trastuzumab + capecitabine. Tucatinib is a potent, selective oral tyrosine kinase inhibitor that showed high efficacy in patients with HER2-positive ABC who were prior exposed to trastuzumab, pertuzumab, and Ado-TDM-1. ${ }^{[3]}$ HER2CLIMB is a Phase 3, randomized controlled trial in patients with HER2-positive $\mathrm{ABC}$ (with or without brain metastasis) that showed that tucatinib + trastuzumab + capecitabine improved progression-free survival (PFS) and OS as compared to trastuzumab + capecitabine. This trial enrolled patients with brain metastasis and $48 \%$ had brain metastasis at baseline.

The 1-year PFS was $33 \%$ for trastuzumab + capecitabine (hazard ratio [HR]: 0.54; confidence interval $[\mathrm{CI}]: 0.42-0.71 ; P<0.001)$. In patients with brain metastasis, the 1 -year PFS was $25 \%$ with tucatinib + trastuzumab + capecitabine and $0 \%$ in patients who received trastuzumab + capecitabine. ${ }^{[4]}$ Tucatinib with Ado-TDM-1 has also shown efficacy in heavily pretreated HER2-positive ABC. ${ }^{[5]}$ The common side effects of tucatinib include diarrhea, hand-foot syndrome, fatigue, nausea, and vomiting. In April 2020, the Food and Drug Administration (FDA) approved tucatinib in combination with trastuzumab and capecitabine, for adult patients with advanced unresectable or metastatic HER2-positive breast cancer, including patients with brain metastases, who have received one or more prior anti-HER2-based regimens in the metastatic setting.

The other treatment option would be trastuzumab deruxtecan. Trastuzumab deruxtecan (DS-8201) is an antibody-drug conjugate composed of an anti-HER2 antibody, a cleavable tetrapeptide-based linker, and a cytotoxic topoisomerase I inhibitor (exatecan). It is FDA approved based on a Phase 2 trial (DESTINY-Breast01) of heavily treated HER2-positive $\mathrm{ABC}$ (median 6 lines of prior therapy) that showed an impressive response rate and PFS of $60 \%$ and 16 months, respectively. ${ }^{[6]}$ The median PFS was 18 months among the patients who had asymptomatic brain metastasis. The common side effects include neutropenia, anemia, and nausea. Patients need to be monitored for cough or shortness of breath as interstitial lung disease (14\%) is a known side effect. The limitations include the exclusion of patients with untreated or symptomatic brain metastasis, Phase 2 design, and immature OS data. The DESTINY-Breast02 trial is an ongoing Phase 3, randomized controlled study (RCT) comparing trastuzumab deruxtecan with trastuzumab + capecitabine and lapatinib + capecitabine in patients with HER2-positive $\mathrm{ABC}$ who had prior exposure to trastuzumab emtansine. The DESTINY-Breast03 is an ongoing Phase 3, RCT comparing trastuzumab deruxtecan with Ado-TDM-1 in patients with HER 2-positive ABC who were prior treated with trastuzumab and taxane.

Neratinib is an irreversible pan-HER2 kinase inhibitor. The NALA trial showed an improved 1-PFS in patients who received neratinib + capecitabine $(38 \%)$ as compared to lapatinib + capecitabine $(15 \%){ }^{[7]}$ Time to intervention for symptomatic CNS disease was delayed in neratinib + capecitabine $(23 \%)$ as compared to lapatinib + capecitabine (29\%). The limitations include unpublished trial, lack of OS data, Grade 3 diarrhea (24\%) with neratinib + capecitabine, and need for loperamide prophylaxis. The NEfERT-T Phase 3 RCT enrolled 


\begin{tabular}{|c|c|c|c|c|c|c|c|}
\hline Phase & $\begin{array}{l}\text { Sample } \\
\text { size }\end{array}$ & Experimental arm & Control arm & $\begin{array}{l}\text { Brain metastasis } \\
(\%)\end{array}$ & Response rate & Median PFS & Median OS \\
\hline 3 & 612 & $\begin{array}{l}\text { Tucatinib + } \\
\text { trastuzumab }+ \\
\text { capecitabine }\end{array}$ & $\begin{array}{l}\text { Placebo } \\
+ \text { trastuzumab + } \\
\text { capecitabine }\end{array}$ & 48 & - & $\begin{array}{l}1 \text {-year PFS } 33 \% \\
\text { versus } 12 \%\end{array}$ & $\begin{array}{l}22 \text { months versus } \\
17 \text { months }\end{array}$ \\
\hline 2 & 184 & $\begin{array}{l}\text { Trastuzumab } \\
\text { deruxtecan }\end{array}$ & - & 13 & $60 \%$ & 16 months & $\begin{array}{l}\text { 1-year OS } \\
\text { (estimated) - 86\% }\end{array}$ \\
\hline 2 & 621 & $\begin{array}{l}\text { Neratinib + } \\
\text { capecitabine }\end{array}$ & $\begin{array}{l}\text { Lapatinib + } \\
\text { capecitabine }\end{array}$ & Included & $\begin{array}{l}33 \% \text { versus } \\
27 \%\end{array}$ & $\begin{array}{l}1 \text {-year PFS } 48 \% \\
\text { versus } 15 \%\end{array}$ & $\begin{array}{l}1 \text {-year OS 87\% } \\
\text { versus } 67 \%\end{array}$ \\
\hline 3 & 479 & Neratinib + paclitaxel & $\begin{array}{l}\text { Trastuzumab }+ \\
\text { paclitaxel }\end{array}$ & 3.7 & $\begin{array}{l}74.8 \% \text { versus } \\
77.6 \%\end{array}$ & $\begin{array}{l}12.9 \text { months } \\
\text { versus } 12.9 \\
\text { months }\end{array}$ & Not estimable \\
\hline 2 & 128 & $\begin{array}{l}\text { Pyrotinib }+ \\
\text { capecitabine }\end{array}$ & $\begin{array}{l}\text { Lapatinib + } \\
\text { capecitabine }\end{array}$ & Excluded & $\begin{array}{l}78 \% \text { versus } \\
51 \%\end{array}$ & $\begin{array}{l}18 \text { months versus } \\
7 \text { months }\end{array}$ & Immature \\
\hline 3 & 991 & $\begin{array}{l}\text { Ado-trastuzumab } \\
\text { emtansine }\end{array}$ & $\begin{array}{l}\text { Lapatinib + } \\
\text { capecitabine }\end{array}$ & Excluded & $\begin{array}{l}44 \% \text { versus } \\
31 \%\end{array}$ & $\begin{array}{l}9.6 \text { versus } 6.4 \\
\text { months }\end{array}$ & $\begin{array}{l}31 \text { versus } 25 \\
\text { months }\end{array}$ \\
\hline 3 & 536 & $\begin{array}{l}\text { Margetuximab }+ \\
\text { chemotherapy }\end{array}$ & $\begin{array}{l}\text { Trastuzumab + } \\
\text { chemotherapy }\end{array}$ & Excluded & $\begin{array}{l}22 \% \text { versus } \\
16 \%\end{array}$ & $\begin{array}{l}5.8 \text { versus } 4.9 \\
\text { months }\end{array}$ & Immature \\
\hline 1 & 99 & $\begin{array}{l}\text { Trastuzumab } \\
\text { duocarmazine }\end{array}$ & - & Excluded & $33 \%$ & 9 months & Immature \\
\hline
\end{tabular}

PFS - Progression-free survival; OS - Overall survival

479 patients with untreated HER2-positive $\mathrm{ABC}$ including asymptomatic brain metastasis and showed that neratinibpaclitaxel was not superior to trastuzumab-paclitaxel. However, patients who received neratinib-paclitaxel had a lower incidence of central nervous system recurrences (HR, 0.48; CI, 0.29-0.79; $P=0.002$ ) and delayed time to central nervous system metastases (HR, 0.45; CI, 0.26-0.78; $P=0.004) .{ }^{[8]}$

Pyrotinib is an irreversible dual pan-HER2 kinase inhibitor. A Chinese Phase 2 study showed an improved response and PFS in patients who received pyrotinib + capecitabine as compared to lapatinib + capecitabine..$^{[9]}$ The median PFS was 18 months with pyrotinib + capecitabine and 7 months with lapatinib + capecitabine ( $\mathrm{HR}, 0.36$; CI, 0.23-0.58; $P<0.01)$. It is currently approved in combination with capecitabine in China for the treatment of HER 2-positive $\mathrm{ABC}$ previously treated with anthracycline and taxane. ${ }^{[10]}$ The limitations include Phase 2 design, small sample size $(n=128)$, immature OS data, and exclusion of patients with brain metastasis.

Lapatinib is a reversible dual tyrosine kinase inhibitor that selectively targets and inhibits HER2 and epidermal growth factor receptor. The EMILIA trial, a Phase 3 RCT, showed that response, PFS, and OS of patients with HER2-positive $\mathrm{ABC}$ who received lapatinib + capecitabine were $31 \%, 6$ months, and 25 months, respectively. ${ }^{[11]}$ The limitations include the exclusion of patients with prior exposure to Ado-TDM-1 and symptomatic brain metastasis. A French Phase 2 trial included 45 patients with HER2-positive ABC with untreated brain metastasis. Among them, 57\% had neurological signs and symptoms and were treated with lapatinib and capecitabine. The intracranial response was $66 \%$ at a median follow-up of 21 months. ${ }^{[12]}$ A study from the United States showed that stereotactic radiosurgery concurrent with lapatinib improved local control without increasing radiation necrosis in HER 2-positive $A B C$ with brain metastasis. ${ }^{[13]}$

Margetuximab is a novel antibody that targets HER2-positive breast cancer with $\mathrm{Fc}$ engineering that alters the Fc receptor affinity. SOFIA trial showed that margetuximab with chemotherapy improved PFS as compared to trastuzumab with chemotherapy. ${ }^{[14]}$ The median PFS with margetuximab + chemotherapy (5.8 months) and lapatinib + chemotherapy (4.9 months) (HR, 0.76; CI, 0.59-0.98; $P=0.033$ ). The limitations include unpublished trial, a marginal improvement in PFS, and immature OS.

Trastuzumab duocarmazine is a HER2-targeted antibody-drug conjugate with cleavable linker duocarmycin payload. In patients with heavily pretreated HER2-positive $\mathrm{ABC}$, this showed a response and PFS of $33 \%$ and 9 months, respectively. ${ }^{[15]}$ The limitations include the Phase 1 study and the small sample size.

Financial support and sponsorship

Nil.

\section{Conflicts of interest}

There are no conflicts of interest.

Manikandan Dhanushkodi

Department of Medical Oncology, Cancer Institute (WIA), Chennai, Tamil Nadu, India

Address for correspondence: Dr. Manikandan Dhanushkodi, Department of Medical Oncology, Cancer Institute (WIA), 38, Sardar Patel Road, Chennai - 600 036, Tamil Nadu, India. E-mail:dmani1982@gmail.com 
Submitted: $17-$ Mar-2020

Revised: 03-May-2020

Accepted: 14-May-2020

Published: 29-Oct-2020

\section{References}

1. Swain SM, Kim SB, Cortés J, Ro J, Semiglazov V, Campone M, et al. Pertuzumab, trastuzumab, and docetaxel for HER2-positive metastatic breast cancer (CLEOPATRA): end-of-study results from a double-blind, randomised, placebo-controlled, phase 3 study. Lancet Oncol 2020;21:519-30.

2. Yardley DA, Tripathy D, Brufsky AM, Rugo HS, Kaufman PA, Mayer $\mathrm{M}$, et al. Long-term survivor characteristics in HER2-positive metastatic breast cancer from registHER. Br J Cancer 2014;110:2756-64.

3. Murthy R, Borges VF, Conlin A, Chaves J, Chamberlain M, Gray T. Tucatinib with capecitabine and trastuzumab in advanced HER2-positive metastatic breast cancer with and without brain metastases: a non-randomised, open-label, phase $1 \mathrm{~b}$ study. Lancet Oncol 2018;19:880-8.

4. Murthy RK, Loi S, Okines A, Paplomata E, Hamilton E, Hurvitz SA, et al. Tucatinib, trastuzumab, and capecitabine for HER2-positive metastatic breast cancer. N Engl J Med 2020;382:597-609.

5. Borges VF, Ferrario C, Aucoin N, Falkson C, Khan Q, Krop I, et al. Tucatinib combined with ado-trastuzumab emtansine in advanced ERBB2/HER2-positive metastatic breast cancer: A phase 1b clinical trial. JAMA Oncol 2018;4:1214-20.

6. Modi S, Saura C, Yamashita T, Park YH, Kim SB, Tamura K. Trastuzumab deruxtecan in previously treated HER2-positive breast cancer. New England J Med 2019;382:610-21.

7. Saura C, Oliveira M, Feng YH, Dai MS, Hurvitz SA, Kim SB. Neratinib+capecitabine versus lapatinib+capecitabine in patients with HER2+ metastatic breast cancer previously treated with $\geq 2$ HER2-directed regimens: Findings from the multinational, randomized, phase III NALA trial. JCO 2019;37:1002.

8. Awada A, Colomer R, Inoue K, Bondarenko I, Badwe RA, Demetriou G, et al. Neratinib plus paclitaxel vs. trastuzumab plus paclitaxel in previously untreated metastatic ERBB2-positive breast cancer: The NEfERT-T randomized clinical trial. JAMA Oncol 2016;2:1557-64.

9. Ma F, Ouyang Q, Li W, Jiang Z, Tong Z, Liu Y, et al. Pyrotinib or lapatinib combined with capecitabine in HER2-positive metastatic breast cancer with prior taxanes, anthracyclines, and/ or trastuzumab: A randomized, phase II study. J Clin Oncol
2019;37:2610-9.

10. Blair HA. Pyrotinib: First global approval. Drugs 2018;78:1751-5.

11. Verma S, Miles D, Gianni L, Krop IE, Welslau M, Baselga J. Trastuzumab emtansine for HER2-positive advanced breast cancer. New England J Med 2012;367:1783-91.

12. Bachelot T, Romieu G, Campone M, Diéras V, Cropet C, Dalenc $\mathrm{F}$, et al. Lapatinib plus capecitabine in patients with previously untreated brain metastases from HER2-positive metastatic breast cancer (LANDSCAPE): A single-group phase 2 study. Lancet Oncol 2013;14:64-71.

13. Parsai S, Miller JA, Juloori A, Chao ST, Kotecha R, Mohammadi AM, et al. Stereotactic radiosurgery with concurrent lapatinib is associated with improved local control for HER2-positive breast cancer brain metastases. J Neurosurg 2019;132:503-11.

14. Rugo HS, Im SA, Wright GL, Escriva-de-Romani S, DeLaurentiis M, Cortes J. SOPHIA primary analysis: A phase 3 (P3) study of margetuximab (M)+ chemotherapy (C) versus trastuzumab $(\mathrm{T})+\mathrm{C}$ in patients (pts) with HER2 + metastatic (met) breast cancer (MBC) after prior anti-HER2 therapies (Tx). JCO 2019;37:1000.

15. Saura C, Thistlethwaite F, Banerji U, Lord S, Moreno V, MacPherson I. A phase I expansion cohorts study of SYD985 in heavily pretreated patients with HER2-positive or HER2-low metastatic breast cancer. JCO 2018;36:1014.

This is an open access journal, and articles are distributed under the terms of the Creative Commons Attribution-NonCommercial-ShareAlike 4.0 License, which allows others to remix, tweak, and build upon the work non-commercially, as long as appropriate credit is given and the new creations are licensed under the identical terms.

For reprints contact: WKHLRPMedknow_reprints@wolterskluwer.com

\begin{tabular}{|l|l|}
\hline \multicolumn{2}{|c|}{ Access this article online } \\
\hline Quick Response Code: & Website: \\
& www.ijmpo.org \\
\cline { 2 - 2 } & DOI: \\
\hline
\end{tabular}

How to cite this article: Dhanushkodi M. Treatment options for patients with brain metastatic disease in HER2-positive breast cancer. Indian J Med Paediatr Oncol 2020;41:735-7. 